and Shubnikov although they are alluded to in the Preface. A few misprints were noted, among them ' $\mathrm{Mg}_{2} \mathrm{AlO}_{4}$ ', 'Schottsky', and on p. 410 'kainite' should read 'kyanite.' The octahedral cleavage of bismuthcontaining galena is suggested to be due to organic impurities, but this has been shown to be due to the precipitation from solid solution of oriented lamellae of a bismuth compound. A closer and more fundamental correlation also could have been made with allied phenomena in other fields, especially metallurgy and surface- and colloid-chemistry. Buckley's book, however, in spite of its shortcomings, goes far to fill the longstanding need for a survey text in English on crystal growth.

Harvard University

C. Frondel

Cambridge, Mass.

U.S.A.

Elements of Optical Mineralogy: an Introduction to Microscopic Petrography. Part II. Descriptions of Minerals with Special Reference to their Optical and Microscopic Gharacters. By A. N. WincheLl, with collaboration of H. Winchell. Pp. xvi+551, with 427 figs. New York: Wiley; London: Chapman and Hall. 4th ed. 1951. Price $\$ 12.50 ; 100 s$.

The third edition of Winchell's book appeared in 1933 and covered 442 pages of text with 362 text figures. The present revised edition, though larger by ninety pages and an addition of more than fifty illustrations, follows the general pattern of its well-known predecessor. Descriptions of most of the minerals recorded since 1930 have been incorporated and a number of discredited species, though not all, have been omitted. There have been some changes in nomenclature, particularly the adoption, which will be welcomed, of $N_{Z}, N_{Y}$ and $N_{X}$ in place of $N_{g}, N_{m}$ and $N_{p}$ and the application of Schuster's rule, previously confined to the feldspars, to the extinction angles of other monoclinic and triclinic minerals.

The greatest change in treatment is in that of the silicates. In the third edition many silicates (described in 43 pages) were placed under the heading 'silicates not yet classified by X-ray studies'. In the new edition this heading has disappeared. The nomenclature of the structural classification now follows closely that of Strunz (Mineralogische Tabellen, 1941) and the classification is extended to all silicates though it is clearly recognised that with many rarer types the $\mathrm{X}$-ray data are still to be sought. Furthermore, for each mineral, where that is possible, a brief statement of X-ray data under the heading 'structural' is now added. As a result of the new data, a considerable number of minerals has been given new crystallographic elements (compared to those in the third edition) but without corresponding change in the accompanying figure relating the position of the indicatrix axes to the morphology. Discrepancies thus occur between some of the text descriptions and the related figure. Either the diagrams should have been revised, or, if that was thought inadvisable, a note of indication of the discrepancy added for the benefit of the reader.
A conspicuous feature of the book is the wealth of diagrams purporting to present the relation between chemical composition and physical (principally optical) properties. The number of such diagrams has been increased from 56 to over 120 in the new edition. A continual striving to attain precise relationships of this kind is in the forefront of mineralogical investigation, but the student should be warned, in view of the present lack of accurately tied data, to treat many of these diagrams with reserve. Some that are presented are so confused with inconsistent data that they should have been omitted-notably those depicting relationships in the chondrodite, cordierite and beryl series. Some other diagrams are of doubtful value. In the treatment of the amphiboles, it is difficult to see the purpose of inserting the complex triangular prism diagrams for 'eight end members (calciferous hornblende)' shown in figures 14 and 15 , and repeated in figures 318 and 325 ; or again for that of the montmorillonite system in figure 275 .

The section devoted to the feldspars, profusely illustrated as before, has been increased by seven pages, principally by an exposition of Nieuwenkamp's method (1948) for the determination of the plagioclase feldspars in random sections. The exposition is insufficiently detailed to be applied by the student without reference back to Nieuwenkamp's memoir, and in a book of this character a much briefer statement should have sufficed. The revision of the feldspar section was fated to be completed before the recent notable advances on the polymorphism and in the thermal and X-ray study of this group had been recorded (1950), and much of the section will accordingly need to be rewritten in the light of these later researches.

Despite some shortcomings to which reference has been made in the preceding paragraphs, Winchell's book retains the deservedly high reputation it enjoyed through successive earlier editions as the outstanding compendium on the optical properties of minerals and as a standard of reference indispensable to every research worker in the field of mineralogy and petrology.

\section{E. Tilley}

Department of Mineralogy and Petrology

University of Cambridge, England

Phase Transformations in Solids. Edited by $R$. Smoldchowski, J. E. MaYer and W. A. Weyl. Pp. 660 with many figures and tables. New York: Wiley; London: Chapman and Hall. 1951. Price $\$ 9 \cdot 50 ; 76 s$.

Au cours du dernier Conseil de Physique Solvay, Sir W. L. Bragg rappelait que l'on pouvait, il y a quarante ans, réunir des 'physiciens' pour parler de 'physique'. Maintenant, l'on ne saurait songer à une telle réunion sans en délimiter étroitement le sujet. Et, même dans un tel cadre, les spécialistes sentent souvent qu'ils sont loin d'être au courant de tout ce qui leur est nécessaire.

C'est pourquoi, maintenant, les livres écrits par un seul homme sont remplacés peu à peu par des œuvres collectives où sont rassemblés les articles d'un grand nombre d'auteurs traitant les différents aspects d'une question. Tel est le cas de Phase Transformation in Solids qui reproduit les communications et-très sommairement d'ailleurs-les discussions d'un Symposium tenu à Cor- 
nell en 1948 sous les auspices du National Research Council. Il est évident qu'une telle mosaïque n'a pas la continuité et la logique d'un traité. Seulement, un seul auteur aurait-il eu la compétence et le courage nécessaire pour écrire un ouvrage d'une telle ampleur? Profitons donc sans regret de toute la masse de documents et d'idées que nous offre cet ouvrage: et le laps de temps (trois ans) écoulé entre le Symposium et la publication du livre est une discrète indication des difficultés qu'a dû surmonter le Comité de Rédaction.

Les articles couvrent bien l'ensemble du sujet, aussi bien du point de vue théorique qu'expérimental. On peut regretter, cependant, que la théorie des transformations ordre-désordre ait été omise; pourtant des travaux très nombreux sur ce sujet ont paru depuis quelques années.

Certains des articles constituent d'excellentes mises au point, faciles à lire, et qui intéresseront en particulier les métallographes. Citons par exemple l'article de Seitz sur la diffusion; celui de Smoluchowski sur la germination; celui de Barrett sur les transformations dans les métaux purs; et de Cohen sur la transformation martensitique. La plus longue étude est l'article de Geisler sur la précipitation des solutions solides; c'est là une revue très détaillée et, malgré cela, claire. La bibliographie contient 830 numéros avec une classification méthodique par sujets. Certes, les conclusions de l'auteur sur la structure des alliages durcis, telles qu'elles sont exprimées dans cet article, ne nous semblent pas toutes justifiées. Il n'en reste pas moins que tous ceux qui travaillent cette question auront à se servir des documents qu'a rassemblés Geisler.

La partie théorique a été traitée par Tisza, Meyer, Kirkwood et Price. Ici, ce ne sont pas des mises au point complètes, mais plutôt des articles spéciaux qui exigent du lecteur une bonne connaissance de la thermo-dynamique statistique; un article comme celui de Kirkwood, par exemple, est très concis et ne peut pas se passer de l'étude des nombreux articles préalables.

Signalons enfin les contributions de Kracek, Schairer et Weyl sur les silicates et les verres, qui mettent bien en évidence l'intérêt des problèmes posés par les transitions dans ces corps et leur grande complexité. Les métallographes auront grand avantage à comparer ces équilibres avec ceux des métaux qui leur sont plus familiers.

En résumé, ce livre donne au lecteur un état encore très actuel de la question, bien que sur certains points on sente déjà les trois ans d'âge des mémoires.

Mais si, au cours des prochaines années, certaines idées sont à réviser, ce sera le fruit des recherches qu'un tel livre n'aura pas peu contribué à rendre plus aisées et plus rapides.

A. Guinier

Conservatoire National des Arts et Métiers 292 rue Saint-Martin, Paris. 3e, France

Structural Crystallography. By N. V. BkLov. Pp. 88, with 58 figs. Moscow: Publishing House of the Academy of Sciences of the U.S.S.R. Price 4 roubles.

Academician Belov, lately recipient of a first-class Stalin prize for his scientific work, is one of the leading exponents in the Soviet Union of the art and science of crystal-structure analysis. Having to his credit the elucidation of many complex structures, principally silicates, and many papers on pure crystallography, his method of teaching the elements of structural crystallography is worthy of attention.

Unfortunately, as this monograph contains neither preface nor introduction, it is left to the foreign reader to deduce for himself the purpose for which it is intended. It would appear that the book contains four lectures for postgraduate students, designed to explain the nature and properties of the space lattice, and presumably part of a more comprehensive course.

The whole development is in terms of the geometrical lattice-the first lecture is called 'The crystalline or lattice state'-and is strict and formal, although full of illustration and explanation. Each new concept is exhaustively discussed as it is introduced. By comparison with many authors the leaning towards Euclidean formality is excessive; for example, nearly half of the first lecture is spent in proving by three different methods that a primitive unit cell cannot contain lattice points not situated at its apices. The Laue and Bragg conditions for the diffraction of X-rays are only mentioned as an explanation for the inclusion of the geometry of the reciprocal lattice. This emphasis on lattice geometry reflects Academician Belov's recommendation of the study of the packing of polyhedra as the fundamental method of analysis, although, of course, he does not scorn advanced Fourier techniques.

Geometrical relationships between the elements of real and reciprocal cells are derived in full, as are the transformations of axes and indices. As special cases of the primitive lattice the 14 Bravais lattices are deduced, the hexagonal/rhombohedral question being clearly dealt with. The rhombohedral cell is derived as a doublycentred hexagonal cell.

The introduction of symmetry elements at a lattice point and their resulting multiplication is studied (both International and Schoenflies symbols are used for describing point groups). The last lecture introduces the various glide planes and screw axes as combinations of point groups and translations but as primary symmetry elements equally with mirror planes and rotation axes. At this point the monograph stops abruptly and space groups are not actually considered.

A few minor misprints were found, including an erroneous reference.

The price (equivalent to about 2 shillings) and the printing $(3,000$ copies) show that the monograph was intended for a wider public than the Institute of Crystallography and there might well be room for an English translation, as no other book examines so fully the concepts of lattice geometry which are the foundation of any crystal-structure analysis.

A. L. Mackay

Birkbeck College Research Laboratory

21, Torrington Square

London W. C. 1, England

Compendium der Kristalkunde. Von W. F. DE JoNG. xii $+260 \mathrm{~S}$. mit $208 \mathrm{Abb}$. und 40 Tabellen. (Holländisch.) Utrecht: Oosthoek. 1951. Preis gulden 16.50.

Im ersten Teil findet die geometrische Kristallographie unter den Untertiteln: Kristallbeschreibung, Kristall- 